\title{
Peasant Agroecological Markets Network: possible platform for a regional eco- agri-food system
}

\author{
Carlos Arturo Aristizábal-Rodríguez ${ }^{1}$ \\ Diego Ivan Angel-Sanchez ${ }^{2}$ \\ Peasant Agroecological Markets Network of Valle del Cauca ${ }^{3}$
}

\begin{abstract}
The health emergency caused by Covid 19 highlighted the food dependency of many cities in the world and Cali and the cities of Valle del Cauca were no exception as they depended on food flows from other regions and countries, so these Entities are part of the corporate food system, to which their rulers delegated food security for their inhabitants. In the same territory and for the last nine years, a second-level organization has been consolidating that brings together 14 peasant agroecological markets and that despite strict confinement measures was able to continue supplying food to consumers in the municipalities of influence that have supported this initiative. The foregoing leads to think that said organization can become a platform for an agroecological food system of regional scope, for which the characteristics that said system should have according to a model based on the principles of agroecology were evaluated.
\end{abstract}

\section{Keywords}

Agroecology, territorial agroecologycal food systems.

\section{Introduction}

The sindemic or synergy of pandemics generated by the coronavirus highlighted the fragility of the corporate food system as denounced by different authors (Altieri \& Nicholls, 2020; Loker \& Francis, 2020; Gliessman, 2020), mainly in the last ten years . This fragility was manifested by the shortages suffered by cities around the world as a result of strict confinement measures decreed by national and local governments (UN, 2020). Which in turn highlighted the enormous food dependency afflicting cities, which in their great majority have delegated their responsibility for the food security of their inhabitants to the market. This is affected by social situations that occur in countries of the global south such as Colombia, which presents alarming figures of poverty (42\% in 2020) and extreme poverty (15.1\%, in 2020) (La República, 2020); that result in high rates of malnutrition (4.8\% for the period 2016-2018) (FA0, 2019), which means that under the current scheme neither availability nor access to food that makes up the human right to healthy food.

\footnotetext{
1 Doctorate in Agroecology (c), Universidad Nacional de Colombia Sede Palmira. caaristizabalro@unal.edu.co

2 Associate Professor, Universidad Nacional de Colombia Sede Palmira. dangels@unal.edu.co

3 redmercados@gmail.com
} 
In this regard, the department of Valle del Cauca in Colombia is not alien to this situation, presenting poverty figures of $34.5 \%$ and extreme poverty of $15.1 \%$ in 2020 (La República, 2020), which were preceded by a state malnutrition of $53.6 \%$ in 2015 (ICBF, 2019). If the context related to food is analyzed, in the territory the same scheme of the Corporate Food System - SAC is presented, at the international level, in which the so-called kilometric foods predominate, produced under the scheme of the Green Revolution - RV (monocultures dependent on petrochemicals), which come from other countries and regions, in many cases ultra-processed, marketed by intermediaries who take most of the price paid by the consumer. This is aggravated because its best lands, more than 223,905ha, are dedicated to the industrial monoculture of sugar cane (Cali Chamber of Commerce, nd), mostly destined to the production of ethanol (65\%) (Fedebiocombustibles, nd) . Problem that is also evident in the hillside areas, where coffee, avocado, citrus and timber monocultures predominate. What has caused erosion and compaction in the soils, overexploitation of water, loss of biodiversity that reflects the virtual disappearance of the tropical dry forest ecosystem, loss of wetlands and contamination of soil, water and air through the road. the use of petrochemical inputs, mainly glyphosate, coupled with social problems such as land dispossession, expansion of the agricultural frontier, unemployment and migration to the cities (Dávalos-Álvarez, 2007).

Situation that means that more than $80 \%$ of the food consumed in Cali (El País, 2020), its capital, comes from other regions and countries and worse still, than peasant families, as is also the case in the other municipalities of the department and in rural areas, where paradoxically they also depend on the kilometric food that the SAC distributes them unevenly, since they have lost the ancestral custom of growing their own food, thus losing their food sovereignty and their biocultural memory. However, in the face of this reality and mainly in hillside areas, peasant families coexist in the territory who have resisted or abandoned the RV model imposed by the state and the companies dedicated to industrial agriculture. Concerned about their health and that of their agroecosystems, they continue to apply their ancestral knowledge through ecological agriculture practices that allow them to preserve their biocultural memory, help mitigate climate change, guarantee their food sovereignty, and sell surpluses in the municipal capitals of the department. . To this end, peasant markets were initially set up with the help of some institutions and in 2009 the Network of Peasant Agroecological Markets of Valle del Cauca - REDMAC was established, with the aim of mutually supporting each other and generating its own Participatory Guarantee System - SPG. . The Network groups 14 fair-type markets, which provide healthy food to part of the population of rural and urban territories (Ángel et al., 2019).

Faced with this situation, mainly in the last decade, proposals have been emerging to the prevailing scheme, such as alternative agri-food systems, sustainable agri-food systems, agroecological food systems and eco-agri-food systems, which together represent a possible way out of the crossroads already raised and thus, to be able to conserve the biocultural memory, improve the health of the ecosystems, help mitigate climate change and guarantee the food sovereignty of the families and the inhabitants of the region in general. In conjunction with the above, agroecology, understood as 
"the discipline,... field of study,... focus, science,... that aims to study agrarian systems from an ecological perspective" (González de Molina, 2011, p.8) and its tripartite nature of science, practice and social movement (Wezel, et al., 2009), from its socioeconomic and cultural dimension, is concerned with a fair and equitable distribution of food.

These ideas lead us to think if the organizational process carried out by REDMAC can be considered as a platform to constitute an Agroecological Food System - SAAE, seen in the light of the approaches proposed by Vaarst et al. (2018), who suggest that the characteristics of a SAAR should be: minimize losses and recycle resources, minimum use of external inputs, contextuality, resilience, multifunctionality, complexity and integration, equity and nutrition. This approach complements the analysis of these characteristics with the 13 socioeconomic principles of agroecology formulated by Dummont et al. (2016) and Ottman (2005), which are: environmental equity, financial independence, market access and autonomy, sustainability and adaptability, diversity and knowledge exchange, social equity, association between producers and consumers, geographic proximity, rural development and conservation of the rural social fabric, shared organization, limited distribution of profits, democratic governance and application of principles in real practice. On the other hand, González de Molina and López-García (2021) propose the following principles to form a territorial agroecological-based agri-food system - SATA: environmental health, economic viability of agroecosystem management, social equity considering access to production factors and distribution of what has been produced and the democratic ability to decide what is produced, how and for whom it is produced. The initiative arises within the framework of the thesis entitled "Strengthening the local resistance strategy of the Network of Rural Agroecological Markets of Valle del Cauca", to opt for the title of doctor in agroecology.

\section{Materials and methods}

The information was collected in 18 farms belonging to REDMAC member families, located in the municipalities of Seville, Tuluá, Buga, Dagua, Restrepo, Guacarí, Palmira and Cali, department of Valle del Cauca, Colombia, complemented with in-depth interviews to the leaders of each of the 14 markets and 5 founding members of the Network, as well as 25 consumers. The farms were selected according to convenience sampling, in which each family voluntarily agreed to participate in the research process. The information was collected through structured and semi-structured interviews, participant observation and elaboration of property maps. A documentary review of the REDMAC statutes and its Life Plan was also made, through a checklist. For the analysis, the following variables were collated, mainly taken from what was proposed by Vaarst et al ::

\section{Results and Discussion}

1. Minimization of losses and recycling of resources: with the exception of three families that do not have enough space and labor, in all the farms agrobiodiversity is used intensively in terms of the generation and use of biomass for human consumption and animal that is fed not only with vegetal species of interest, but also 
with diversity of flowers and weeds; in addition to the generation of surpluses for the market. Similarly, families take advantage of the excreta generated by animals to fertilize their crops. The foregoing can be seen in the following graph that shows the integration of the animal component in agroecosystems, there the estimated level is shown from lowest to highest, where the highest rating is 5 and the lowest is 0 (Figure 1).

Figure 1. Level of integration of the animal component in the agroecosystem

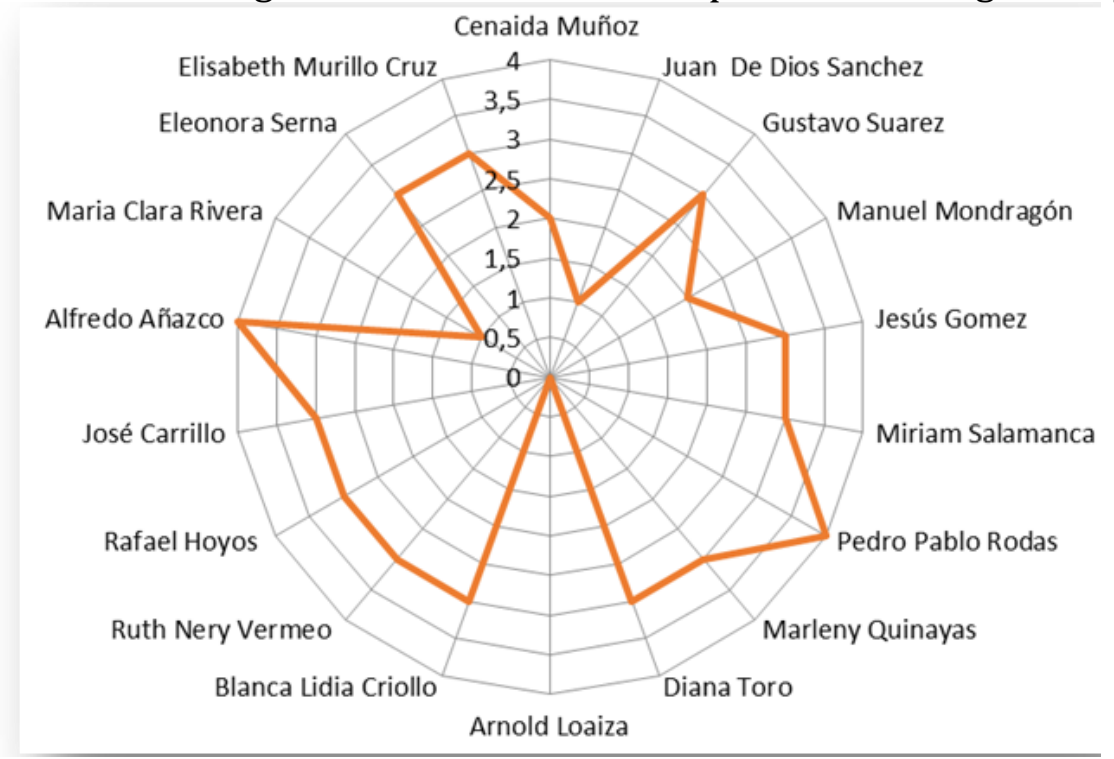

Source: The authors

2. Minimum use of external inputs: of the studied farms, only one is self-sufficient in terms of the use of external inputs, while 7 families (44.5\%) obtained between 1 and 3 points, which can be considered as a low dependency. In the medium level there are 4 families and in the medium high and high levels there are 4 families, most of which must buy concentrated feed for their animals because the extension of their farms does not allow them to have enough biomass for their food. (Figure 2). 
Figure 2. Level of dependence on external inputs

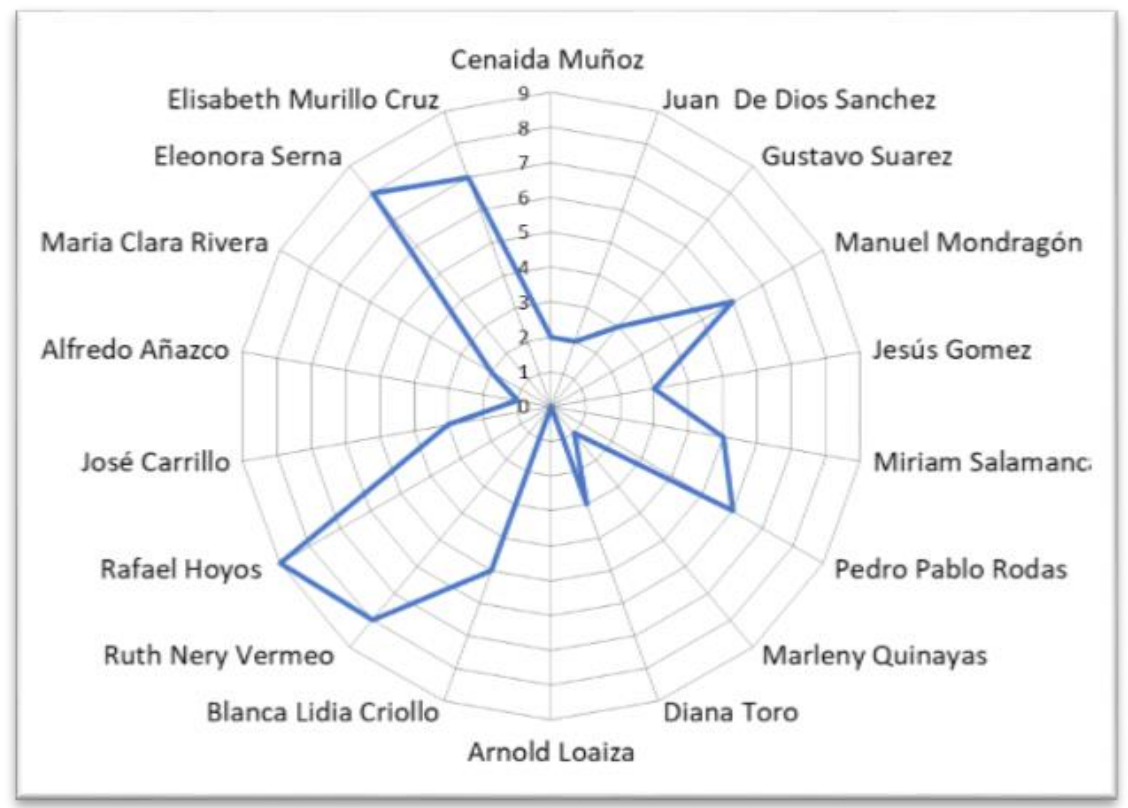

Source: The authors

3. Contextuality: according to what Vaarst et al. (2018), the agri-food system of which REDMAC is a platform is developed in the context of each municipality in its area of influence, since food is produced there and consumed initially by each family, and then the surplus is sold in the municipal seat. nearest and in the capital of the department. For this, families are key actors who constantly contribute and co-create their knowledge to the community through activities to support producers such as farmer-to-farmer training workshops within the framework of the SPG, as well as workshops on knowledge and flavors with consumers, where knowledge of the use of food, spices and medicinal plants is shared.

4. Resilience or capacity to adapt: the emergency unleashed by the coronavirus pandemic evidenced the ability of the markets belonging to the Network to adapt to respond to the strict confinement measures dictated by the Colombian government in 2020 and 2021, regarding the implementation of the required biosecurity measures, in addition to the implementation of home deliveries for families who could not leave their homes during the emergency, tasks in which consumers from some of the markets collaborated. From the ecological point of view, all the families highlighted the ability of their agroecosystems to resist the changes inherent to climate change, in terms of excessive periods of rain or drought, for which they are protected by their different strata and living cover.

5. Multifunctionality: the REDMAC platform also fulfills additional functions to the productive ones, such as education, which is carried out through tours of the farms of the families that make up the markets, in this case 7 of the studied families receive visits Directed by colleges, universities, market consumers and also producers. In 
these visits, the way agroecosystems work, their diversity and integration, the conscious consumption of healthy food, as well as the benefits obtained from practicing agroecology, are presented. On the other hand, through the Rural Welcoming program, 10 (55.5\%) of the surveyed families receive tourists interested not only in appreciating the agrobiodiversity of their farms, but also in learning about agroecology as a philosophy and a way of living and see the world. On the other hand, all the farms visited have welcomed students and research groups from different universities to develop undergraduate and postgraduate theses, as well as research projects and university extension, thus materializing an investigative function and creation of knowledge through horizontal dialogue of knowledge.

6. Complexity and integration: this characteristic is manifested through the different interactions that occur between producer families and the markets to which they belong through their associations, savings funds, production support programs and training. On the other hand, families also interact with the Network through training events and community support projects, such as seed conservation, improvement of production capacities and soft skills. REDMAC also integrates with governmental, nongovernmental and academic organizations through participation in projects and in political advocacy spaces such as Municipal Councils for Rural Development - CMDR, the Regional Committee of Agroecology and Fair Trade Organizations - CROAC, and the National Family Agriculture Network - RENAF.

7. Equity: multiple actors are involved in the REDMAC platform that contribute to the functioning of what is proposed as a regional food system. At the moment 3 women are part of the board of directors, one of them being the president, which reflects the importance that women have had in the entire organizational process of the Network, thanks to their perseverance and resistance in the markets. On the other hand, for more than a year the organization has been carrying out a project for the inclusion of its young people through different activities that include political training, as well as the formulation of productive projects on their farms. The members of the Network also actively participate in the SPG through dialogue committees, which are in charge of making accompanying visits to farms in order to support agroecological production from a technical point of view. All these activities are carried out in a mutual and horizontal way.

8. Nutrition: both agroecosystems and producer and consumer families that belong to and receive the influence of REDMAC, maintain healthy diets that guarantee survival through resilience. This is how agroecosystems have their greatest strength in agrobiodiversity, complemented by the integration of its components through flows of matter and energy present in the biomass that circulates there. This results in the productive capacity of agroecosystems and the diversity found in them, which is finally expressed in the variety of supply in the markets. In them, importance is given to species of commercial interest, as well as to the so-called forgotten and underutilized species, thus seeking to preserve the biocultural memory of the territory through its planting and use at the food level. 


\section{Conclusions}

After analyzing all the characteristics proposed by Vaarst et al., (2018), it can be concluded that REDMAC has managed after nine years to consolidate an organizational process that serves as a platform to constitute an agroecological food system. However, factors to be improved cannot be ignored, such as the low production capacity and the need for greater integration with consumers and their support so that they are linked collectively and in an organized way to the social process. Their link is important to validate GSP processes, promote the scaling of the process and therefore of agroecological production by expanding the base of consumers who demand a greater offer of products, which would promote the agroecological transition processes for farmers that still apply the conventional RV model.

\section{References}

Altieri, M. A., \& Nicholls, C. I. (2020). Agroecology and the reconstruction of a postCOVID-19 agriculture. The Journal of Peasant Studies,47(5), 881-898. https://doi.org/10.1080/03066150.2020.1782891

Ángel, D., Aristizábal, C., REDMAC. (2019). Construyendo desde la base una opción de vida: experiencia de la Red de Mercados Agroecológicos Campesinos del Valle del Cauca - REDMAC. En A. Acevedo-Osorio y N. Jiménez-Reinales (comps). La agroecología. Experiencias comunitarias para la agricultura familiar en Colombia. (pp.161-181). Bogotá: Corporación Universitaria Minuto de Dios - UNIMINUTO, Editorial Universidad del Rosario. Recuperado de https://editorial.urosario.edu.co/pageflip/acceso-abierto/agroecologia-experienciascomunitarias-para-la-agricultura-familiar-en-colombia.pdf

Cámara de Comercio de Cali. (s.f.). Azúcar líder de la agroindustria del Valle. https://www.ccc.org.co/azucar-lider-de-la-agroindustria-en-el-valle/

Dávalos-Álvarez E. (2007). "La caña de azúcar: ¿una amarga externalidad?". Revista Desarrollo y Sociedad, n. o 59: 117-164.https://doi.org/10.13043/dys.59.4

Dumont, A., Vanloqueren, G., Stassart, P. \& Baret, P. (2016) Clarifying the socioeconomic dimensions of agroecology: between principles and practices, Agroecology and Sustainable Food Systems, 40:1, 24-47, DOI: 10.1080/21683565.2015.1089967

El País. (2020). "Tenemos productos, no entremos en pánico": directora de Cavasa hace llamado a la calma. https://www.elpais.com.co/valle/tenemos-productos-noentremos-en-panico-directora-de-cavasa-hace-llamado-a-lacalma.html?utm source=facebook\&utm medium=Social\&utm campaign=ampliarnoticia\&fbclid=IwAR1ljrId8evFEkf ZWANWVyP8c00pwsl]7TgygZVcMSpNIJvUCbXpW Nvs4w 
FAO, FIDA, OMS, PMA y UNICEF. 2019. El estado de la seguridad alimentaria y la nutrición en el mundo 2019. Protegerse frente a la desaceleración y el debilitamiento de la economía. Roma, FAO. Consultado el 21 de mayo de 2020. http://www.fao.org/3/ca5162es/ca5162es.pdf

Fedebiocombustibles. (s.f.). Caña de azúcar, el gran motor de la economía en el Valle del Cauca. https://www.fedebiocombustibles.com/nota-web-id-2848-titulocaña de azúcar el gran motor de la econom\%C3\%ADa en el valle del cauca.htm

Gliessman, S. R. (2020). Transforming food and agriculture systems with agroecology. Agriculture and human values, 37, 547-548. https://doi.org/10.1007/s10460-020-10058-0

González de Molina, M. (2011). Introducción a la agroecología. Imag Impressions. https://www.socla.co/wpcontent/uploads/2014/Cuaderno tecnico agroecologia pag-prot.pdf el 14 de febrero de 2019.

González De Molina, M. \& Lopez-Garcia, D. (2021): Principles for designing Agroecology-based Local (territorial) Agri-food Systems: a critical revision, Agroecology and Sustainable Food Systems, DOI: 10.1080/21683565.2021.1913690

Instituro Colombiano de Bienestar Familiar. (2015). Encuesta Nacional de la Situacion Nutricional. Consultado el 21 de mayo de 2020. https://www.icbf.gov.co/bienestar/nutricion/encuesta-nacional-situacionnutricional\#ensin 3

La República. (2020). Más de 21 millones de personas viven en la pobreza y 7,4 millones viven en pobreza extrema. : https://www.larepublica.co/economia/mas-de21-millones-de-personas-viven-en-la-pobreza-y-74-millones-en-pobreza-extrema$\underline{3161813}$

Loker, A., \& Francis, C. (2020). Urban food sovereignty: Urgent need for agroecology and systems thinking in a post-COVID-19 future. Agroecology and Sustainable Food Systems, 44(9), 1118-1123. https://doi.org/10.1080/21683565.2020.1775752

ONU. (2020). El abastecimiento de alimentos en tiempos de covid-19. https://nacionesunidas.org.co/noticias/actualidad-colombia/el-abastecimiento-dealimentos-en-tiempos-de-covid-19/

Ottmann, G. \& Sevilla, E. (2004). Las dimensiones de la agroecología. En Instituto de Sociología y Estudios Campesinos Universidad de Córdoba (Ed.), Manual de olivicultura ecológica (p.11-24). Argos impresores: Córdoba. Recuperado de http://oe.confolio.org/scam/29/resource/84 
Vaarst, M., Getz, A., Chappell, M., Brinkley, C., Nijbroek, R., Arraes, N., Andreasen, L., Gattinger, A., Fonseca, G., Bossio. D., \& Halberg, N., (2018) Exploring the concept of agroecological food systems in a city-region context, Agroecology and Sustainable Food Systems, 42:6, 686-711, DOI: 10.1080/21683565.2017.1365321

Wezel, A., Bellon, S., Doré, T., Francis, C., Vallod, D., \& David, C., (2009). Agroecology as a science, a movement and a practice. A review. Agronomy for Sustainable Development, Springer Verlag/EDP Sciences/INRA, 29 (4). DOI: 10.1051/agro/2009004 